Volume 71

Issue 3 Texas Gulf Sulphur 50th Anniversary

Symposium Issue

Article 21

January 2018

\title{
The Coasian Firm and Insider Trading, Revisited
}

James C. Spindler

University of Texas Law School

\section{Recommended Citation}

James C Spindler, The Coasian Firm and Insider Trading, Revisited, 71 SMU L. REV. 967 (2018)

https://scholar.smu.edu/smulr/vol71/iss3/21

This Article is brought to you for free and open access by the Law Journals at SMU Scholar. It has been accepted for inclusion in SMU Law Review by an authorized administrator of SMU Scholar. For more information, please visit http://digitalrepository.smu.edu. 


\title{
The CoAsian Firm And Insider TrAding, REVISITED
}

\author{
James C. Spindler*
}

\begin{abstract}
I present an economic model of insider trading building upon Haddock \& Macey's classic analysis of trading by the manager of a Coasian firm (i.e., a firm in which agency costs do not exist). Due to current shareholders' status as expected sellers of shares, Coasian insider trading allows shareholders to expropriate outsiders via the managerial proxy and any signaling value of insider trading is eliminated by shareholders' biased incentives. Adverse selection results. If a system of credible disclosure exists, an insider trading ban results in more disclosure, more efficient prices, and lower illiquidity costs. While the case for insider trading in the Coasian firm may be weak, insider trading can provide positive social benefits where some form of agency cost exists. Insights from the Coasian model include that shareholder incentives may lead to undesirable capital markets activity, greater agency costs may result in preferable social outcomes, and deterrent penalties must take into account shareholder incentives.
\end{abstract}

\section{TABLE OF CONTENTS}

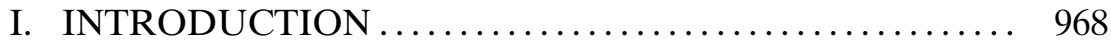

II. THE HADDOCK \& MACEY MODEL: COASIAN CORPORATE GOVERNANCE AND INSIDER

TRADING ............................. 970

III. EXTENDING THE ANALYSIS WITH A FULLY

COASIAN FIRM .......................... 973

A. Insider Trading AND THE EXPROpRIATION OF Outside Traders ............................. 974

B. Insider Trading Fails as a Signal of Value .... 977

C. Is an Insider Trading Ban Socially Preferable With a Fully Coasian Firm? ................ 980

D. Agency Costs Can Make Insider Trading More Valuable ............................... 981

IV. CONCLUSION: WHAT USEFUL INSIGHTS DOES THE NO-AGENCY COST MODEL PROVIDE? ....... 983

* Sylvan Lang Professor of Law, University of Texas Law School; Professor, McCombs School of Business, University of Texas at Austin. I would like to thank Jonathan Macey. 


\section{INTRODUCTION}

$\mathrm{T}$

EXAS Gulf Sulphur ${ }^{1}$ is notable for, among other things, the policy position that insider trading is not fundamentally different from informed trading by outsiders. In its boldest interpretation, as subsequently developed and interpreted by the SEC, Texas Gulf Sulphur would prohibit both insider and outsider informed trading, even where the outsider's information does not "emanate[ ] from a corporate source nor ... deal with a corporate issuer or its affairs." ${ }^{2}$ How and why such a view developed-and ultimately came to be rejected-is the subject of other work (including in this volume). ${ }^{3}$ From a welfarist perspective, though, a consideration of Texas Gulf Sulphur fifty years later requires revisiting the justification (or lack thereof) for equal treatment of inside and outside information: is there a reason to allow one but not the other?

As one might expect, prior literature has already explored this question at some length. The economic analysis of insider trading to date has revolved around two principle theoretical frameworks: market effects, ${ }^{4}$ and agency. ${ }^{5}$ The market effects critique considers primarily the effect of in-

1. SEC v. Texas Gulf Sulphur Co., 401 F.2d 833 (2d Cir. 1968), cert. denied, 394 U.S. 976 (1969).

2. Arthur Fleischer, Jr., Robert H. Mundheim \& John C. Murphy, An Initial Inquiry Into the Responsibility to Disclose Market Information, 121 U. PA. L. REV. 798, 802 (1973) (citation omitted).

3. Professor Langevoort describes the development and ultimate rejection of that view and attributes it to practical concerns of enforcement and the day-to-day workings of the capital market, which is largely run by market professionals who seek to make informed outsider trades. See Donald C. Langevoort, From Texas Gulf Sulphur to Chiarella: A Tale of Two Duties, 71 SMU L. Rev. (2018). Providing a contrasting view, Professors Macey and Haddock attribute the modern development of insider trading prohibitions, which allow outsider trading relatively unfettered, to regulatory capture by market professionals who view inside traders as unwelcome competition. See David D. Haddock \& Jonathan R. Macey, Regulation on Demand: A Private Interest Model, With an Application to Insider Trading, 30 J. OF L. \& ECON. 311, 314-17 (1987) [hereinafter Haddock \& Macey, Private Interest].

4. On the market effects front, there is no intrinsic reason to believe that insider trading and informed trading by outsiders serve markedly different functions. From the perspective of the hapless liquidity trader or market-maker, it does not matter whether one loses to an insider as opposed to an informed outsider. The insider's advantages-cheaper and more accurate information-are not necessarily socially bad since they may allow price efficiency to occur at a lower overall cost. The market effects analyses that argue against insider trading have mostly focused on potential anti-competitive effects. Professors Fishman and Hagerty, for instance, propose a model in which inside traders can drive out informed traders owing to their informational advantage, leading to less efficient stock prices. See Michael J. Fishman \& Kathleen M. Hagerty, Insider Trading and the Efficiency of Stock Prices, 23 RAND J. OF ECON. 106, 113 (1992). However, the price efficiency result persists only under certain conditions, and even then it is unclear whether the overall social welfare effects are positive or negative: While prices are less efficient, informed traders spend less on deadweight research costs. See, e.g., id. at 110 n.6, 112-15. Others have focused on the lack of competition insider traders face. See generally Nicholas L. Georgakopoulos, Insider Trading as a Transactional Cost: A Market Microstructure Justification and Optimization of Insider Trading Regulation, 26 ConN. L. Rev. 1 (1993).

5. The agency cost literature has focused on how bad, exactly, are agency costs and to what extent are private contracts able to remedy them. Coasianists, such as Manne, Haddock \& Macey, assert that firms could prohibit insider trading if they wished (such as by 
sider trading on market efficiency and liquidity. The inside trader is treated as a sort of informed-trader-on-steroids, whose information is cheaper, more timely, more accurate, and perhaps less subject to competition than outside information traders. The agency critique focuses on the manager's flawed relationship with the firm, asking the question: what might a disloyal manager do in order to maximize her insider trading profits? These arguments are ably summarized in prior literature, ${ }^{6}$ but suffice it to say that the conclusions have been mixed.

The contribution that I offer here bears mostly on the agency critique. There is a general consensus that the worse agency costs and the greater impediments are to complete contracting between shareholders and manager, the greater the case becomes for banning insider trading. ${ }^{7}$ The point of the instant article is to explore why that is not actually true, at least as a general proposition.

As a point of departure, I utilize the Haddock \& Macey model of a Coasian firm, whose shareholders choose whether or not to allow insider trading. ${ }^{8}$ I take the assumption of the Coasian firm to the logical extreme: ${ }^{9}$ the manager does what the shareholders want, all the time, only subject to the shareholders' willingness to bankroll the activity. There are no agency costs, and it is almost as though the shareholders are piloting the manager by remote control. In such a case, insider trading becomes entirely unworkable.

The reason is that shareholder incentives are not benign-certainly not when it comes to the prospect of selling shares to outsiders. The firm's

charter amendment) and that insider trading opportunities may provide valuable incentives that are otherwise difficult to formulate by contract. See HenRy G. MANNE, Insider Trading And the Stockmarket 138-41 (1966); see also Haddock \& Macey, Private Interest, supra note 3 . Those arguing against insider trading claim the opposite: Insider trading is beyond the ability of shareholders to control or cabin, enforcement is difficult or impossible, and insider trading exacerbates agency costs by unwinding compensation incentives and distorting managerial behavior. See, e.g., Reinier Kraakman, The Legal Theory of Insider Trading Regulation in the United States, in European Insider Dealing 47, 47 (Klaus Hopt \& Eddy Wymeersch eds., 1991).

6. Professor Beny, in particular, provides an excellent summary. See Laura Nyantung Beny, Insider Trading Laws and Stock Markets Around the World: An Empirical Contribution to the Theoretical Law and Economics Debate, 32 J. CorP. L. 237, 241-56 (2007).

7. "The debate about whether private contracting is more efficient than government regulation of insider trading is closely related to the debate about whether insider trading is efficient." Id. at 256; see also id. at 252-57 (describing the Coasian debate over the extent of feasible contracting and its effect on insider trading).

8. See David D. Haddock \& Jonathan R. Macey, A Coasian Model of Insider Trading, 80 Nw. U. L. Rev. 1449, 1449 (1986) [hereinafter Haddock \& Macey, Coasian Model].

9. I use the term "Coasian firm" in a sense similar to that in which Haddock \& Macey do: The firm provides the ability to contract efficiently among the firm's stakeholders (for present purposes, the manager and the shareholders). My version of the Coasian firm is somewhat more extreme. As will be seen, I assume, for instance, that the manager's trades can be as large as shareholders may desire, and that no informational leakage occurs from the firm that the shareholders do not desire. Note, however, that the model is not generally Coasian, in the sense that efficient contracting between the firm and outsiders (such as market professionals) is not allowed. Thus, it is assumed infeasible to have such efficient niceties as a pre-commitment by the firm not to engage in fraud or other manipulative conduct. 
current shareholders - the ones who decide firm policy at any place and time-are the firm's complete owners, and any sales of shares must come from them. They thus stand in the position of sellers and have the incentives of sellers-namely, to make sales at as high a price as possible. ${ }^{10}$ Where the manager acts merely as the shareholders' proxy, we have, in effect, the combination of inflationary incentives and asymmetric information that leads to adverse selection (the familiar "lemons problem") in other sales contexts. Via the manager, the shareholders externalize trading losses and other costs onto outside parties and hence engage in insider trading strategies without regard to whether those strategies are socially efficient. Further, the potential signaling role of insider trading is undercut by shareholders' inflationary incentives; the shareholders' desire and ability to exploit the signal to their own advantage eliminates the signal's credibility.

These findings have implications for scholarship, law, and policy. They suggest that the focus on eliminating firm agency costs as a proxy for maximizing social welfare is not correct, at least with regard to capital markets activity. ${ }^{11}$ The fact that insider trading could serve malign shareholder ends implies that placing responsibility on shareholders may be appropriate, and possibly the optimal liability strategy. ${ }^{12}$ Further, since shareholder incentives to manipulate prices are large, the requisite deterrents will be increasingly large as agency costs decrease. Finally, in terms of a direction for scholarship, the dramatic effect of corporate governance on the desirability of insider trading indicates that there is much yet to be gained from models that integrate corporate governance and capital markets activity in the spirit of the original Haddock \& Macey analysis.

\section{THE HADDOCK \& MACEY MODEL: COASIAN CORPORATE GOVERNANCE AND INSIDER TRADING}

Three decades ago, in the golden age of law and economics, Professors Haddock \& Macey proposed an elegant model of integrated firm governance and insider trading. ${ }^{13}$ The gist of their argument was that in a reasonably well-run firm (what they call a "Coasian firm"), shareholders

10. See infra note 23 and accompanying text.

11. This is, of course, not a new point. Historically, there existed significant skepticism over shareholders as proxies for social welfare. See, e.g., William W. Bratton \& Michael L. Wachter, Shareholders and Social Welfare, 36 Seattle U. L. Rev. 489, 492-96 (2012). The more recent view has been to view shareholders as the residual claimaint on the firm and hence in the best position to promote efficient production, which may be significantly related to social welfare. See id. at 497.

12. This is also not a new point. The same period of time as the Haddock \& Macey analysis gave rise to a significant and sophisticated literature on the efficiency of vicarious liability. See Steven Shavell, Economic Analysis of Accident Law 128-31 (1987). See generally Frank H. Easterbrook \& Daniel R. Fischel, Limited Liability and the Corporation, 52 U. CHI. L. Rev. 89 (1985); Lewis A. Kornhauser, An Economic Analysis of the Choice Between Enterprise and Personal Liability for Accidents, 70 CAL. L. Rev. 1345 (1982); Alan O. Sykes, The Economics of Vicarious Liability, 93 YAle L. J. 1231 (1984).

13. See Haddock \& Macey, Coasian Model, supra note 8. 
would only allow insider trading when it benefits them. This suggests that the practice may not be socially undesirable, particularly since shareholders appear to internalize much of the costs and benefits. In the model, insider trades occur against the shareholders themselves. When the manager buys shares, the counterparty is a shareholder. When the manager sells, she sells short, and the counterparty is a shareholder. ${ }^{14}$ Under such assumptions, the costs of insider trading are largely, if not entirely, borne by the firm's shareholders.

At the same time, the shareholders in a Coasian firm also bargain with the manager over the wage. As is customary in economic principal-agent models, the manager commands a market wage; under assumptions of, say, competitive pressure to bargain for the manager's job, the manager will, in expectation, receive exactly the market wage. What does this mean for insider trading? If the manager enjoys expected utility from insider trading, this utility will allow the wage to be lower, saving the shareholders money. Under assumptions of risk neutrality, whatever profits the manager takes are completely rebated to the shareholders, at least in expectation.

In total, the shareholders bear the costs of losing to the manager on her inside trades, yet they have the benefits of the trades rebated back to them. This should be a wash, unless inefficiencies crop up. The main inefficiency that Haddock \& Macey propose is managerial risk aversion, although any friction that makes the managers gain less than the shareholders' trading losses ought to suffice. Based on just this model so far, these inefficiencies, if they exist, are internalized, and shareholders ought to allow insider trading only when it is not inefficient.

That is not, however, the end of Haddock \& Macey's analysis. Suppose that if the manager does not take advantage of the inside information, it is subsequently discovered by outsider traders (what we might commonly call in such models "informed traders," who research in order to gain an informational advantage in trading). If the manager is risk-averse (or his trading is otherwise costly), it may be that a more socially efficient outcome is to allow outside, informed traders to take advantage of what would otherwise be the manager's inside information. So, for example, if the manager is risk-averse but the outsiders are risk-neutral, letting the trading opportunity go to the outsider expropriates shareholders, but does so efficiently. It is just a transfer, and so, from a Kaldor-Hicks perspective, is neutral.

Notwithstanding social efficiency, shareholders would not like this. What had formerly been the manager's profits, some fraction thereof being rebated to the shareholders, have now become outside traders' prof-

14. See id. at 1461. Note that the assumption that the insider always trades against current shareholders cannot be correct. Possibly Haddock \& Macey considered that the purchaser of the shares ultimately becomes a shareholder. However, the current shareholders and future shareholders may be largely different, and it is doubtful any particular shareholder will have his successor shareholder's interests at heart. 
its, with no rebate whatsoever back to the shareholders. Shareholders in such an instance would choose to allow insider trading even if it was inefficient.

Does this militate toward a mandatory ban on insider trading instead of letting shareholders make their own decisions? Not quite. In the first place, it may be that shareholders, instead of outsiders, are next in line after managers to appropriate insider information opportunities. If so, shareholders would themselves prohibit insider trading if it were inefficient. Second, the fact that investors differ in their ability to exploit information-i.e., which investors would be next in line to use the information? - suggests endogeneity in terms of who will be a shareholder. In particular, an insider trading ban would lead to the firm's shares being exclusively owned by informed traders. Ordinary run-of-themill (noise-trading) shareholders would face constant threats of expropriation with each trade, and hence would exit the market, leaving it to those with better expropriative capabilities. ${ }^{15}$

This latter result does not sound good. With a ban, the average Joe no longer has a place at the table in the U.S. securities markets-or else can only maintain parity by placing his money, for a fee, with a professional money manager who can undertake precautions against expropriation by better informed traders. Such defensive action constitutes deadweight precaution costs, a form of inefficiency; and of course, there are distributional consequences in that small investors may lose out. In contrast, even if insider trading creates some inefficiencies, it has positive countervailing effects for small investors who can now stand their ground against the informed traders by trading, in effect, via their managerial proxy. The net effect of insider trading could be positive.

Thus, in sum, Haddock \& Macey's elegant argument suggests that insider trading is a relatively cost-efficient way for shareholders to protect themselves from expropriation by informed outside traders. Insider trading is both a product of, and tool for maintaining, good corporate governance by small and dispersed investors.

However, as with any model, no matter how ingenious, there are questions that arise as we add complexities to it. This Article now takes up some of these questions. To begin, is it realistic to assume that the manager can only trade with shareholders as opposed to outsiders? If not, then trading losses are not necessarily internalized, and shareholders may not make efficient choices. Further, in a truly Coasian firm, we might imagine that the manager is simply a proxy for the interests of shareholders. Would that not be equivalent to every shareholder being a construc-

15. This is an extreme result. A more middle-of-the-road result would occur if, as is commonly thought, there are also exogenous, non-information-based reasons for trading (i.e., noise trading). For example, if investors purchase securities because they have cash inflows and desire the expected return (better than leaving it in the bank), or if investors sell securities because they have sudden needs for cash, then some noise-trading investors may continue to trade in the firm's shares. 
tive insider? And, in such a context, are shareholder incentives good? These considerations, as shown below, will have serious consequences.

\section{EXTENDING THE ANALYSIS WITH A FULLY COASIAN FIRM}

In this Part, I expand upon the Haddock \& Macey framework with a few twists. Specifically, I change three major assumptions in the model. First, I relax the assumption that the manager always trades against the firm's shareholders. Second, I consider the shareholders' own trading incentives: the firm's current shareholders themselves are, in expectation, going to be net sellers of the firm's shares in the future. Third, I allow the firm to be fully Coasian in the sense that the manager acts loyally to maximize current shareholders' well-being, and I allow a broader set of activities than do Haddock \& Macey.

The players in this model consist, on the firm side, of its manager and its shareholders. It is assumed that shareholders and the manager may strike a private, ${ }^{16}$ but binding, arrangement among themselves. In effect, the manager acts perfectly loyally and in the best interests of the firm's current shareholders. As is conventional in liquidity models, outsiders consist of three types of traders: informed traders (who may research in order to learn about the true value of the firm); noise traders (who trade for reasons exogenous to the model, such as sudden demand for, or an excess of, cash); and market makers (who act as intermediaries for all trades and impose a bid-ask spread). These three types of outside market participants create the familiar dynamic of illiquidity costs that arise from informational uncertainty. ${ }^{17}$

The question of interest is the shareholders' strategic choice of whether and how to allow the manager to engage in insider trading. As it turns

16. This is a point of departure from the Haddock \& Macey model, in which contracting is done via the charter and is observable. Whether the shareholders' choice is observable or not has potentially significant bearing on the outcome: A public commitment might allow coordination and overcome Prisoners' Dilemma-type problems, whereas a private or ex post choice may not. In general, I will assume that "good" corporate oversight entails enough ongoing discretion by shareholders or their representatives that choices are made unobservably and without precommitment. For instance, the board could, in the interests of shareholders, renegotiate the managers' compensation contract, grant more stock, or otherwise enable or limit insider trading in ways not immediately apparent to outsiders. In actual practice, it does not appear to be the case that public companies bind themselves to a particular compensation scheme via the corporate charter, and instead boards of directors retain substantial discretion in rewarding or punishing corporate executives.

17. In the standard liquidity model of Copeland \& Galai or Glosten \& Milgrom, the possibility of expropriation by better informed traders leads market makers to impose a bid-ask spread. See generally Thomas E. Copeland \& Dan Galai, Information Effects on the Bid-Ask Spread, 38 J. OF Fin. 1457 (1983) [hereinafter Copeland \& Galai]; Lawrence R. Glosten and Paul R. Milgrom, Bid, Ask, and Transaction Prices in a Specialist Market with Heterogenously Informed Traders, 14 J. of FIN. ECON. 71 (1985) [hereinafter Glosten \& Milgrom]. The costs of the spread are borne by noise traders, which may include the firm's shareholders. Informed traders expend deadweight research costs and make trading profits, market makers break even in expectation from the imposition of their spread, and noise traders fund the informed traders' profits. 
out, and as I develop in the rest of this section, insider trading in a fully Coasian firm presents major problems. Insider trading may be used as an offensive weapon by the Coasian firm's shareholders to expropriate outsiders. It is no longer the case that shareholders internalize trading gains and losses, and therefore no longer make choices reasonably in line with social efficiency. Further, shareholder incentives (those of a seller of securities) undercut the signaling value of insider trading. The absence of agency costs seriously limits, if not eliminates, the social utility of insider trading.

\section{A. Insider Trading AND the Expropriation of Outside Traders}

As in the Haddock \& Macey set-up, suppose that there is some probability at any given time that the firm experiences a material event in which the value of the firm goes either up or down by a significant amount. Such events could be a new business project, an earnings report, a merger proposal, the realization of contingent obligations-any sort of materially good or bad information. If the firm discloses the event, it is instantly and efficiently priced by the market maker. ${ }^{18}$ Suppose further that the manager learns of the information prior to its disclosure and has the opportunity to undertake trades and make trading profits. What happens under our assumptions of a loyal manager who acts to benefit her current shareholders?

It turns out that what will happen depends on whether the information was positive or negative; the manager's trading strategy will be asymmetric. Before getting to that, though, consider the trading mechanics that arise when the insider enters a trading order. In either case, the manager's trade passes through the market maker, who sets the bid-ask spread to compensate for the expected value of expropriation by betterinformed traders, effectively passing the costs on to others. ${ }^{19}$ If the order is a "buy" based on positive information, the market maker attempts to match the manager's buy with a corresponding sell order. If it is a "sell" based on negative information, the market maker will attempt to match with a buy order.

Take the positive information "buy" order case first. Who is going to be the insider's selling counterparty in such a case? The firm's shares are owned in their entirety by the firm's shareholders. Thus, putting aside

18. This assumes that the information requires no special skill to process, which may be largely true of information such as earnings reports and managers' forecasts of earnings.

19. Either the market maker or the noise trader will directly bear the cost of expropriation. If the price corrects before the market maker matches the informed order with a noise order, the market maker bears the loss and vice-versa. The bid-ask spread accounts for the market makers expected losses, effectively passing them on to the noise traders. See Stanislav Dolgopolov, Insider Trading and the Bid-Ask Spread: A Critical Evaluation of Adverse Selection in Market Making, 33 CAP. U. L. REv. 83, 126 (2004). 
short sales by outsiders (which cannot be sustainable in the long run), ${ }^{20}$ the good news counterparty must be one or more of the firm's shareholders. Shareholders bear the trading losses in this case and some portion (though likely not all) ${ }^{21}$ of any illiquidity costs as well. However, the manager's trading profits are rebated to the shareholders via the compensation contract. The Haddock \& Macey efficiency result largely obtains: the bulk of costs and benefits are internalized onto the firm's stakeholders, and a well-governed firm would allow such trades only if they are efficient.

Consider next the negative information case. If the manager's information is negative, the manager's order will be a "sell," and the market maker matches the manager's order with a corresponding buy order. A purchaser of shares could be either an outsider looking to become a shareholder or a shareholder seeking to purchase more shares. But over time, shareholders must be net sellers (they, as a group, own the entire firm, and any net sales of shares must come from them), ${ }^{22}$ and some positive portion of the insider's sale of shares must, in expectation, be matched with an outsider's buy order. The incidence of the trading losses must fall upon outsiders, at least partially, as will much of the liquidity costs. The shareholders, however, enjoy the insider's trading profits as they are again rebated to shareholders via the compensation contract. The shareholders enjoy a free lunch of sorts.

Troublingly, in this negative information case, the firm fails to internalize the costs and benefits of insider trading. The efficiency result no longer obtains-shareholders may choose to permit inefficient insider selling, even though they would not have permitted inefficient insider purchases. Overall, then, there is an asymmetry: the firm's shareholders will choose efficiently when the insider is buying (based on positive information), but may not choose efficiently when the insider is selling (based on negative information). We would expect to see, for instance, that shareholders are at best indifferent to insider purchases (it is a wash for them), but would be highly desirous of insider sales. Shareholders would, accordingly, encourage insider selling.

What drives this result? The firm's current shareholders own the entire firm and are the ones who have the ability to control its corporate gov-

20. If outsiders can sell short, then the manager could be trading against an outsider in this scenario. This would undermine the point that insider trading should be efficiently constrained in the positive information case. There are reasons to think that short sales will not play a significant role here, however. Short sales do eventually need to be covered; short sales must generate an offsetting amount of real purchases over time. Unless we believe that short-selling disproportionately occurs when undisclosed positive information shocks occur (which seems unlikely to be the case), outsider purchases must generally equal or exceed outsider shorts.

21. Shareholders would bear less than all liquidity costs since there may be other trading going on as well, which must pay the market maker's spread. For instance, it could be that the manager buys one share, a noise-trading shareholder sells two shares, and an outsider noise trader buys one share. Each trader would pay the spread; hence, a quarter of the illiquidity costs are borne by the outsider.

22. See infra note 23. 
ernance, including whether the manager engages in insider trading. They are the ones who strike the Coasian bargain with the manager and whose interests the manager loyally serves. As owners, the shareholders also stand in the position of prospective sellers. Whether or not some shareholders add to their holdings, any net sales of the firm's shares to outsiders must come from the current shareholder group. ${ }^{23}$ As sellers, shareholders do not like rules or practices that harm sellers, such as deflation of the firm's shares or sales at a bargain rate. Conversely, shareholders prefer seller-benefitting practices such as price inflation, generally, ${ }^{24}$ and in the context of insider trading, insider sales at inflated prices. This is true even in the case where shareholders are heterogeneous-some shareholders may be long-term holders, some may be short-term sellers, and some may expect to acquire more shares-provided that shareholders and the manager can bargain among themselves to maximize their joint welfare. ${ }^{25}$ When one adds up the payoff functions of these various types of shareholders and aggregates them, what one ends up with is the payoff function of a seller. In a well-governed firm, then, we should expect the firm to be managed so as to maximize the welfare of a shareholder who has some expectation of selling his share - that is, with a proseller bias.

A couple further observations are in order. One is that, in the fully Coasian firm, insider trading should be large. Even if shareholders themselves cannot be made privy to the information, the shareholders would be happy to provide the manager access to large volumes of stock that she can sell in order to profit when the firm is over-valued. The manager's profits in excess of her reservation wage would be, as in the Haddock \&

23. Some mathematics helps to illustrate the fact that current shareholders must be net sellers of the firm's securities. Suppose first that the firm's shareholders are heterogeneous. In such a case, each shareholder has the same probability of selling out their share over a certain unit of time. Letting $\pi$ denote the probability of selling out, each shareholder's expected payoff is $\pi p+(1-\pi) v$, where $p$ is the trading price received for selling out, and $v$ is the ultimate value received by holding onto the share. See James C. Spindler, Vicarious Liability for Bad Corporate Governance: Are We Wrong About 10b-5?, 13 Am. L. AND ECON. Rev. 359, 369-71 (2011) [hereinafter Spindler, Vicarious Liability].

With heterogeneous shareholders, aggregate incentives are, it turns out, the same as in the homogeneous case. If we assume joint welfare maximization among the shareholders (as the Coasian firm does), then the results are exactly the same, too. Suppose for simplicity that there are three shareholders with contrasting time horizons: one who may sell, one who may buy more, and one who will simply hold the firm's shares. Their payoff functions are, respectively: (1) $U_{\mathrm{S}}=\pi \mathrm{p}+(1-\pi) \mathrm{v}$; (2) $\mathrm{U}_{\mathrm{B}}=\mathrm{v}+\gamma(\mathrm{v}-\mathrm{p})$; and (3) $\mathrm{U}_{\mathrm{H}}=\mathrm{v}$. The variable $\gamma$ in the buyer-shareholder's payoff function is the likelihood that the buyer-shareholder will purchase an additional share in the future. So long as outside purchasers are expected to purchase some shares of the firm, it must be the case that $\gamma<\pi$. Summing up, we obtain the joint welfare function of the firm's initial shareholders: $\Sigma U i=(\pi-\gamma) p+(3+\gamma-\pi) v$. By substituting $\pi_{z}=(\pi-\gamma) / 3$, we can rewrite the aggregate payoff function as $\Sigma U_{i} / 3=\pi_{z} p+$ $\left(1-\pi_{z}\right) \mathrm{v}$. This is exactly the same form of payoff as the homogeneous shareholder case. See James C. Spindler, Optimal Deterrence When Shareholders Desire Fraud, _ Georgetown L. J. (forthcoming 2018) (manuscript at 10-11), https://papers.ssrn.com/sol3/papers.cfm? abstract_id=3121230 [hereinafter Spindler, Optimal Deterrence].

24. See id. (showing that the firm's current shareholders are net sellers and have thereby a general preference for price-inflating misreporting).

25. See supra note 23. 
Macey model, rebated to the shareholders in the form of a lower wage. Indeed, it is entirely conceivable that the manager's wage would be negative: the volume of insider trading profits may dwarf the compensation that the manager herself commands. Thus, rather than the relatively small trades that characterize current insider trading cases (as exemplified by prosecutions, at least), ${ }^{26}$ in a world of Coasian firms where insider trading is not otherwise prohibited, insider trading would be enormous. It would amount to, in essence, the ability of the shareholders themselves to sell out on the basis of insider information, performed derivatively through their loyal proxy, the manager.

Second, this analysis answers a question that a Coasian might otherwise find vexing: why would shareholders ever choose to permit insider trading when one could, with the Coasian power to contract, simply replicate the payoffs of insider trading via a compensation scheme? For instance, if it is believed that in state-of-the-world A ("state A"), insider trading would yield expected profits of $\$ 1$, and that in state-of-the-world $\mathrm{B}$ ("state B"), insider trading would yield expected profits of $\$ 2$, one could simply write a contract that pays the manager $\$ 1$ in state A and $\$ 2$ in state B. This has the added salutary effect of reducing the risk that the manager bears (Haddock \& Macey assume that insider trading is inherently risky-e.g., that the manager in state A would face 50/50 odds of $\$ 0$ or $\$ 2$ from insider trading). Instead of forcing the manager to bear whatever her risky trading realization is, she enjoys the sum-certain of $\$ 1$ in state $\mathrm{A}$ and $\$ 2$ in state B. The synthetic insider trading scheme is thus superior to the authentic one, except for the fact that actual insider trading is likely to be funded by outsiders. This would, of course, be the reason why shareholders might prefer actual insider trading-from their ex post perspective, it amounts to a free lunch.

\section{B. Insider Trading Fails as a Signal of Value}

What does this analysis say about the role of insider trading as a potential signaling device? One of the principal arguments in favor of insider trading is that it serves as a credible signal of the firm's value, where credible disclosure is otherwise difficult or impossible to undertake. Such signals contribute to price efficiency, which may have real economic effects by leading to more efficient capital allocation, better governance, or the reduction of deadweight research and precaution costs. In the absence of meaningful antifraud rules, corporate disclosure may be viewed simply as cheap talk. In contrast, when the insider puts her money where her mouth is, markets may draw a stronger inference about her valuation of the firm. Under such a narrative, the permission of insider trading leads to greater price efficiency and/or lower illiquidity costs. Indeed,

26. Andrew R. Sorkin, Study Asserts Startling Numbers of Insider Trading Rogues, CNBC MARKETS (Jun. 17, 2014), https://www.cnbc.com/2014/06/17/study-asserts-startlingnumbers-of-insider-trading-rogues.html [https://perma.cc/J47F-S3XS] (asserting that the average insider trade was $\$ 1.6$ million). 
there are entirely reasonable arguments that, in terms of market effects, insider trading may be preferable to informed trading by outsiders. Among other things, insiders may have better, cheaper information, which saves on deadweight research costs, and it may be easier for market participants to discern whether an insider is trading than whether an informed market outsider is trading, leading to quicker and less costly price discovery. ${ }^{27}$

Unfortunately, the assumption of a Coasian firm undercuts such a positive narrative. If we consider the incentives of shareholders, it turns out that they may not in fact desire accurate signaling, and this can make it difficult or impossible for insider trading to convey actual informational content. The reasoning is similar to that explored above: shareholders, as owners of the firm, have biased incentives with regard to price movements. Current shareholders stand in the position of sellers of the firm's shares-they own all of it. Any net future sales must come from them and the exercise by them of their control over the manager will take this into account.

In particular, as sellers, we should expect that shareholders will generally desire price inflation and disdain price deflation. To the extent that shareholders control the firm's ability to send signals of value (as they must in a firm without agency costs), the signals sent will reflect these preferences. In particular, shareholders would direct the manager to purchase shares in an attempt to artificially raise the price of the stock; costs borne by the manager of this strategy are rebated back to her by the shareholders. By artificially pushing the price higher, shareholders enjoy higher trading profits as they sell their shares. The greater their propensity to sell, the greater their potential profit, the less they are invested in the firm's long term prospects, and the more they would be willing to invest in a false signal of positive value. ${ }^{28}$

In contrast, shareholders would generally not desire the manager to signal negative information, even if it is true. ${ }^{29}$ Doing so would push the price lower, and thus the greater the shareholders' propensity to sell, the greater their losses due to depressed short-term trading profits.

27. See, e.g., Dennis W. Carlton \& Daniel R. Fischel, The Regulation of Insider Trading, 35 Stan. L. Rev. 857, 866-72 (1983); Haddock \& Macey, Coasian Model, supra note 8, at 1452-55. As discussed above, such a result is debatable, and there are models that suggest if insider traders are not subject to competition, price efficiency may decrease.

28. More formally, the shareholders' representative payoff function is $\mathrm{U}=\pi p+(1$ $\pi) v$. See supra note 23 . The greater the propensity to sell, $\pi$, the more weight is placed on the short-term trading price, $p$, and the less weight is placed on the ultimate realization of the firm's production, $v$.

29. What about the possibility that the information will leak out into the market anyways? So long as the non-disclosure or non-correction can make the price distortion last longer, the general effect is the same. The assumption of Coasianism eliminates the possibility that the manager disloyally divulges the true information to the market. Informed traders, on the other hand, may be able to replicate the information via their own research, but perhaps less precisely and less quickly than would occur with disclosure. Even with informational leakage, then, shareholders would desire that the manager not disclose, as the greater period and amount of distortion benefits shareholders. 
So, in sum, the Coasian firm would engage in insider purchases to signal (falsely or not) positive information, and would not engage in insider sales to signal negative information (whether or not negative information has been obtained). How is this consistent with the result supra in Part III.A, in which shareholders encourage insider sales, but are at best indifferent to insider purchases? The preliminary answer is that it depends on the anticipated strength of the signal of insider trading. If the signal value is high, that militates toward more insider buying; if the signal value is low, that means more insider selling.

Consider some out-of-equilibrium hypotheticals. At one extreme, if the insider trading has no signaling value (that is, no amount of insider trading affects the price), shareholders would be happy to have the manager sell overpriced shares to outsiders and in fact would direct the manager to sell as much as possible, rebating the proceeds back to the shareholders via the compensation contract. Shareholders would be indifferent to insider purchases, since it nets out through the wage. At the other extreme, if insider trading is taken as a highly credible signal (that is, insider trading of just one share has an immediate and significant effect on price), shareholders would encourage the manager to purchase (a relatively small amount of) shares to drive up the price, which enables shareholders to sell off over time at inflated values.

Of course, in equilibrium, the signal's credibility is endogenous: everyone anticipates such dynamics, and neither extreme is likely to survive. The game we are left with (remembering the assumption of no agency costs) is simply that of an informed seller (the shareholders, acting through their managerial proxy) and an uninformed buyer (the outside market traders). Without the presence of noise trading or the ability to undertake precautionary research, any offer to sell is a conclusive signal of over-valuation. Offers from the seller to buy cannot really occur since there does not exist an additional source for such purchases, as the seller already owns all of the firm. In equilibrium, with only those players, the market experiences extreme adverse selection, an instance of the notrade theorem in which no trading occurs, since any offer to trade signals adverse information. ${ }^{30}$ With the presence of noise traders and the ability for traders to research, some trade is possible at discounts, subject to liquidity costs and deadweight precautionary costs. ${ }^{31}$

30. See Paul Milgrom \& Nancy Stokey, Information, Trade and Common Knowledge, 26 J. OF ECON. TheORY 17, 17-27 (1982).

31. This is form of the standard trading problem enunciated by Glosten \& Milgrom, and Copeland \& Galai. See Copeland \& Galai, supra note 17, at 1468; Glosten \& Milgrom, supra note 17, at 72. Positive bid-ask spreads compensate market makers for the risk of expropriation, and the informed trader's profits (in this case, the seller's) are funded in expectation by noise traders. 


\section{Is an Insider Trading Ban Socially Preferable With a Fully Coasian Firm?}

As the argument stands so far, the fully Coasian firm presents a problem for insider trading proponents. Because of current shareholders' biased incentives, a loyal manager who acts to benefit current shareholders would engage in insider trading in order to expropriate outsiders for the benefit of shareholders. Adverse selection results with price discounts, bid-ask spreads, and deadweight precaution costs. In such a case, would a ban on insider trading make things better, or worse?

So far, the answer is not necessarily "yes" since there is a benefit to insider trading in that uninformed, noise-trader investors will be more willing to hold the firm's shares. The insider acts as the current shareholders' champion, protecting shareholders from expropriation by outside informed traders. In terms of real economic effects, the costs of capital formation may be lower, since noise investors are more willing to become shareholders. The exact outcome depends on things such as the effect of the insider trading on outside informed traders and the ability of the market to distinguish informed trading from noise trading. In the best case, looking again to Haddock \& Macey, we could imagine that the insider drives the informed traders from the market, taking their place; all then proceeds as before. Under those circumstances, permitting insider trading may well be preferable. Of course, other, less extreme scenarios may be more likely, and coming to a definite conclusion, pro or con, may not be possible.

However, a potentially decisive variable, not yet examined, is disclosure. What effect does an insider trading ban have upon disclosure? Should we hope that, by its nature, a "disclose or abstain from trading" rule leads ineluctably to accurate and timely disclosure? Such disclosure, if it is indeed forthcoming, would solve virtually all of the problems discussed above: market prices adjust rapidly-if not quite instantaneously-to disclosure, maximizing price efficiency and minimizing illiquidity costs. This leaves little, if any, room for informed trading profits (at least based on company information), whether by insiders or outsiders.

Alas, the analysis presented here indicates that credible and timely disclosure faces the same sorts of problems as insider trading does because it will not be freely forthcoming from a Coasian firm. Under a ban, it is true that shareholders do benefit from accurate disclosure of positive information. A loyal manager could protect the firm's current shareholders from expropriation by simply disclosing the positive information as it occurs and before the outsider informed traders can discover it. Yet one must also consider that shareholders benefit from positive disclosures generally-i.e., without regard to whether they are true. The Coasian manager thus has incentives to lie since a lie allows shareholders to sell out at inflated prices while it remains undiscovered. At the same time, shareholders do not benefit from negative disclosure, whether or not such is 
true, since depressing the share price leads to lower shareholder payoffs as they sell out. Absent some countervailing cost or liability for misstatements or omissions ${ }^{32}$ the equilibrium outcome is that the manager of the Coasian firm will withhold negative information and falsely report positive information in order to maximize current shareholder welfare.

That said, if a credible disclosure regime can be imposed on the firm (meaning that lying becomes an infeasible strategy), ${ }^{33}$ then it seems that banning insider trading in advance of the disclosure will have unambiguously good effects. The ban encourages voluntary disclosure of positive information by the loyal manager; this protects shareholders against expropriation by outsiders. Unfortunately, the same is not true for negative information. If she can, the manager instead chooses to remain silent, mimicking a no-event firm, attempting to buy time for her shareholders to sell out. ${ }^{34}$ Even so, such an outcome is relatively good, and insider trading would only make things worse: the firm's shareholders are largely protected from expropriation, and shareholder expropriation of outsiders is limited.

\section{Agency Costs Can Make Insider Trading More Valuable}

As described above, if there exists a credible disclosure system, the case for banning insider trading in a world of Coasian firms is strong, since the ban results in more disclosure, greater market efficiency, and lower illiquidity costs. The potential benefits of insider trading - as an efficient incentive mechanism, as a defensive bulwark for small shareholders, and as a credible signal of value-are overshadowed, if not absent, in a Coasian firm.

However, the fact that a ban may be optimal for a fully Coasian firm does not mean that a ban is, in actuality, optimal. To the contrary, the best case for insider trading is in a distinctly non-Coasian firm where substantial agency costs do exist. The existence of any form of agency cost is not by itself sufficient, of course. For insider trading to fulfill its potentially positive functions, one needs to explore exactly what the extent of agency costs are and delineate the feasible bounds of contracting and precommitment.

32. The consideration of optimal liability in such a situation is the focus of prior work. See generally Spindler, Optimal Deterrence, supra note 23; Spindler, Vicarious Liability, supra note 23.

33. For present purposes, such a regime could be either self-imposed through shareholder precommitment or externally imposed as by a regulatory system of mandatory disclosure.

34. The nondisclosing manager attempts to mimic a firm that has undergone no information event. This assumes that disclosure of unchanged status-i.e., "no information event has occurred"-is not feasible. If no-event disclosure is feasible, then we should expect complete unraveling (i.e., universal voluntary disclosure) in order to protect shareholders from outside information traders who would otherwise buy the stock at a discount. In such a case, the combination of an insider trading ban and voluntary credible disclosure regime leads to a first-best outcome. 
Such an inquiry is beyond the scope of this paper ("Coasian firm" is in the title, after all), but we could take a speculative stab at what some sufficient conditions might begin to look like. Suppose the compensation contract is observable and not subject to renegotiation; this prevents the shareholders and managers teaming up to manipulate the signal or to engage in insider-trading-by-proxy. Suppose also the manager is subject to some liquidity limitations, meaning that her trades cannot be arbitrarily large; this prevents the total expropriation of other parties (whether it be shareholders or outsiders) so that they are still willing to play the game. In such a situation, the manager's trading, based on maximizing her own self-interest, may provide a useful signal and manageable incentive device. For instance, suppose a somewhat disloyal manager comes to learn positive information. Disclosure may be a poor option: perhaps she is viewed as not credible (she might lie in an attempt to save her job or otherwise increase her compensation), or perhaps she does not want to disclose for fear of personal liability. Instead, she purchases some shares, placing her own money on the line, to benefit herself. The purchases, observed by the market maker, have the salutary effect of signaling the positive information to the marketplace. Even though the purchases, ex post, come at the expense of current shareholders, the shareholders of the nonCoasian firm, in this case, may well prefer the insider trading to occur since it protects them from further expropriation by outside information traders. ${ }^{35}$

This example, though it seems reasonable, assumes some things that need to be explained. In particular, why can the shareholders not bribe the manager to send a false trading signal? Why must we rely on trading as a signal and not on disclosure? Beyond simply assuming them to be the case, there must be fundamental limitations on shareholders' ability to contract with the manager and limitations on the ability to renegotiate that contract. The trick is that such limitations need to not only make insider trading work but also be necessary. Consider the problem: if shareholders could write a detailed, public, non-renegotiable algorithm that controls the manager (perhaps putting it in the corporate charter), then the algorithm could provide that the manager will only buy or sell a certain amount of securities in certain circumstances. Certainly, insider trading would be a credible signal in such a case. The problem is that this hypothetical proves too much: if shareholders can write such detailed algorithms of managerial behavior, why can they not simply provide for disclosure in such circumstances? It must be at least as credible as the insider trading itself, ${ }^{36}$ and one cannot readily justify insider trading

35. The same would not be true of insider selling, however.

36. The argument has been made that the firm may not wish to give away its secrets, but disclosure need not do this. The manager could disclose, "Our value has gone up," or, to be even more detailed, she could say, "Our value has gone up by $\$ 5$ per share." If the algorithm is credible, then this should suffice. There is no need to say, "We have preliminarily discovered $\$ 5$ per share worth of valuable mineral deposits at the following latitude and longitude," thus spilling the firm's beans. 
under such assumptions.

In the real world, of course, perfect contracting is not possible. The inability of robots to do the job of the manager implies that the discretion and judgment of actual human beings, as opposed to some contractual algorithm, is (as yet) required to run the modern firm. Similarly, precommitment to a set compensation scheme appears to be highly limited in practice, though for reasons that are harder to divine. The average compensation scheme of a large, publicly traded corporation allows for discretion and renegotiation. The board can always choose to pay the manager more, true up her options, or renew or fire her after her term is up, and the manager herself is always free to quit (depending on the extent to which non-competes and liquidated damages are enforced). Firms, for their part, do not precommit to not sell overvalued equity, to not accept buyout offers at too high a price, nor to buy back underpriced equity. Precommitment could clearly be valuable, at least in these theoretical models, but why do we not see more of it in practice?

In any event, more work along these lines is needed. For the time being, however, the analysis here shows that the absence of agency costs raises serious problems for insider trading. The addition of agency costs may make insider trading less harmful and more beneficial than the Coasian model allows. An interesting insight is that agency costs are not always bad; shareholders themselves have some bad incentives that agency costs may constrain. This is a broad point, one that encompasses corporate activities beyond just insider trading. It implies that instead of concocting increasingly draconian schemes to combat agency costs, the question that corporate and securities law scholars should address is a more nuanced one: what are the parameters of agency costs within the firm given contracting technology, and what role does that leave, or not, for regulatory intervention?

\section{CONCLUSION: WHAT USEFUL INSIGHTS DOES THE NO-AGENCY COST MODEL PROVIDE?}

This article has expanded the Haddock \& Macey model to show that insider trading is problematic under assumptions of a Coasian firm (that is, a firm without agency costs). Insider trading becomes a tool by which shareholders may utilize the manager's informational advantage to expropriate outsiders. The potential market benefit of insider tradinggreater price efficiency-fails to hold up as shareholders would, via their managerial proxy, use any signaling content of insider trading to manipulate the signal to their own advantage by inflating prices.

What does this highly theoretical model have to tell us? Several things, hopefully. First, there is a prescription for securities law scholarship: an analysis of a firm's capital markets behavior, including disclosure and trading, must take into account the firm's governance and the incentives of shareholders themselves. There has been a tendency to assume that, were it not for disloyal managers, all would be right with our capital mar- 
kets. The analysis here shows that this is not the case; ${ }^{37}$ shareholders themselves have impure motives. Unfortunately, despite Haddock \& Macey's example from three decades ago, there has been relatively little work (particularly formal work) in the securities law literature that attempts to integrate governance and capital markets behavior in a rigorous way.

Second, we should bear in mind that corporate agency costs are ambiguous in any consideration of social welfare. That is, if shareholders are inclined to do some bad things, eliminating agency costs would not necessarily improve the world. This is not a new point, ${ }^{38}$ although, perhaps since Enron, scholarship has lost sight of it in favor of degenerate manager narratives. But more germane to the instant inquiry, and more novel, is the insight that the reduction of firm agency costs will not necessarily improve either corporate disclosure or the capital markets in which their securities trade. I have shown this with regard to reporting behavior in other work, ${ }^{39}$ and as shown here, it is difficult to see insider trading fulfilling a useful role in a Coasian firm.

Third, to the extent we need legal rules against fraud and manipulative behavior, those rules (and the penalties thereunder) must recognize the magnitude of the incentives at play. If shareholders allow or encourage insider trading because it benefits them, then in terms of magnitude, the requisite deterrent penalties must be shareholder-sized, instead of manager-sized. In other words, they will have to be large. Shareholders of a firm with a $\$ 10$ billion market capitalization reasonably have incentives properly counted in the billions, whether it be to grow the firm (presumably good) or inflate its price (presumably bad) or expropriate outsiders (also presumably bad).

Consider a final puzzle that illustrates these points: shareholders pay the manager a relatively short-term, performance-based bonus worth up to $\$ 10$ million that encourages both productive effort and, sadly, manipulation of the firm's stock price. The manager withholds information and undertakes a series of trades that do, in fact, push the price higher for some time. This garners benefits to shareholders who partially sell off before the price corrects. Let us say the selling shareholders gain $\$ 100$ million; the manager herself makes a small trading profit of $\$ 100,000$. The question is: what is the right deterrent penalty, and on whom is it best placed? The amount of the manager's trading profits is clearly too small. Looking to the compensation contract delivers a bigger number, but if we fine the manager, say, $\$ 10$ million, the shareholders might simply raise the performance bonus to $\$ 20$ million and so on. Indeed, until the fine gets to the level of the shareholders' trading gains (\$100 million), it is not

37. See also Spindler, Optimal Deterrence, supra note 23; James C. Spindler, Vicarious Liability for Managerial Myopia, 46 J. of Legal Stud. 161, 161-63 (2017) [hereinafter Spindler, Managerial Myopia]; Spindler, Vicarious Liability supra note 23.

38. See Bratton \& Wachter, supra note 11.

39. See Spindler, Optimal Deterrence, supra note 23; Spindler, Managerial Myopia, supra note 37. 
certain that the manipulative conduct would be deterred. With regard to who should bear the fine, placing liability of such magnitude on the manager is problematic; rather, the size of the requisite penalty may militate in favor of vicarious liability.

In closing, there is much that a Coasian model of the firm and its capital markets activity can tell us. Managers may not be the problem; shareholders themselves are not angels. While the truly Coasian firm is a theoretical construct, shareholders and their firms are well-incentivized to solve agency cost problems. To the extent they do so, we may encounter worse, rather than better, corporate behavior. 